\title{
Tertiary education dropout- general tendencies for the last generations of students
}

\author{
Elena-Alina (FEJER) VOAIDEȘ - COJAN •, Theofild-Andrei LAZĂR・
}

\begin{abstract}
Higher education dropout, or abandonment, represents a contemporary worldwide socioeconomic problem that may be one of the main barriers in the future efforts of the younger generations to bring the world economy forward. Why do students leave higher education prematurely? What can be done to help solve this problem? Does our Higher Education System have a coherent support system to prevent dropout? are the core questions on this important issue. The role of education in the young generation's development and the different factors that support or impede this process represent frequently researched topics in the field of applied socio-human sciences, especially during the last decades that are also characterised by important changes in the educational services delivery.

The current article constitutes the preliminary work for a future doctoral thesis that aims to investigate the issue of contemporary educational dropout in Romanian universities following data from the last decade. Firstly, some theoretical elements on educational dropout in general will be explored, starting by defining the concept, continuing with the exploration of the main theories and finalising by detailing the main factors that influence university dropout.

The last part of the present work follows as a study case the dropout rates of the last three generations of bachelor level students from a social sciences faculty of a state university from Romania. Based on secondary data analysis, the dropout rates are calculated in four steps in order to reveal the dynamics of the process during a bachelor study cycle, being presented the specificities of all four departments of the faculty.
\end{abstract}

Keywords: tertiary education, dropout rate, risk factors.

\section{Introduction}

Even if international research in the domain belongs to different ideological currents, it always highlights the importance of school and the role it plays in the educational development of the child. The educational system supports the dynamics of contemporary society, all over the world, and especially in Romania, a country which is in a stage of changes and reorganizations of new paradigms, which value and inspire modern pedagogies based on the discoveries of human developmental psychology.

Higher education, with all its structures, its internal processes, and external influences, goes through a process of conceptual and organizational transformation which promotes a new paradigm of academic education trying to respond to the needs of a dynamic society that is constantly reforming. The existence of a quality education system that is

•PhD Student, West University of Timișoara, Romania elena.voaides@e-uvt.ro

- Associate Professor, West University of Timișoara, Romania theofild.lazar@e-uvt.ro 
accessible to all is the most important condition for the coherent development of a state and the reduction of inequities among the population, both economically and socially. In order for this condition to be met, it is important that education is considered a priority for all decision-makers in a state and treated with due responsibility. University dropout has negative long-term effects on social development and economic growth. Innovation and growth are based on the skilled workforce: reducing the European average early school leaving rate by one percentage point would give the European economy almost half a million potential young skilled workers each year. Students come to university for a variety of reasons, ranging from clear goals related to their future academic and professional careers to leaving home, having fun, finding new friends, meeting parents' expectations, postponing market placement work and so on. Most of the students are being attracted by the mirage of student life or, perhaps, by the prestige of the institution. Some of the main reasons which conduct to students' dropout are represented by dissatisfaction with motives and expectations, unrealistic expectations, as well as their lack of clarity/specificity, emotional preparation and poor academic skills, adaptive difficulties (shock), and marginalization from the academic process. Adaptive difficulties are both academic and social, ranging from those related to workload management, independent study, and responsibility for one's learning, to broader management of time, budget, social life, emotional issues, and so on.

\section{Theoretical considerations on educational dropout at university level}

In Romania, concerns about access and equity in higher education are older, having roots in the pre-, interwar, and communist periods. The literature marks a series policies examples that encourage children of peasants and workers, respectively from disadvantaged backgrounds, to access secondary school and afterward to higher education: from school construction and the founding of new universities, massive investments in teacher training and special scholarships granted a diversity of categories of pupils and students.

Given the special conditions under which the reform takes place, like rampant globalization, accelerated technical and scientific developments and the IT revolution, as well as its area of action, structure, and content of studies, harmonization of cycles and programs, scientific research, criteria for assessing program quality education and learning outcomes, we must admit that academic reform is in a continuous process, a process of permanent adaptation to the constantly changing economic and social realities. Given that the education system is a conservative one - with great inertia, all over the world - changes in this area require thorough, adequate training. A great vulnerability of the education system is found when graduates do not have the ability to quickly enter the labour market and capitalize on their intelligence in high-tech fields. As a result of the demographic decline, the number of students is constantly decreasing, which increases the competition between universities - the dynamic ones with shorter study durations being more attractive for young people. Higher education in developed 
countries has been in the process of repositioning itself in recent decades in terms of its economic and social role. However, the dominant discourse in the field of higher education development is that of the knowledge-based economy. Therefore, higher education must, on the one hand, respond to the skills training required by an increasingly dynamic labour market and, on the other hand, become a driver of continuous innovation. Therefore, higher education tends to become in many countries an important sector of the economy, in international competition.

Arguments for the need to strategically address the issue of dropping out of university are also outlined from the perspective of the desideratum, imperatives, and recommendations for higher education existing in the agendas and official documents of the European Union. The Europe 2020 strategy imposes as major objectives at the level of the European Union and the Member States the reduction of the early school leaving rate below $10 \%$ and the increase of the share of the population with higher education between the ages of 30 and 34. The strategy associates higher levels of education with better income at individual level and with general economic development at societal level (Johnstone and Marcucci, 2010). From this perspective, the National Strategy for Sustainable Development of Romania (2008) has as medium and long term objectives, among others, the positioning of the Romanian education and training system at the level of higher performances in the EU, respectively the significant approach to the EU average regarding the educational services offered in rural areas and for people from disadvantaged or disabled backgrounds. Mass education is associated with the democratization of society, with equitable, non-discriminatory access to education in general and to tertiary education in particular. "Despite the importance of education for individual and societal development", Cummings (2007, p. 273) points out that "in the information society, the school in its classical form finds it difficult to cope with information alternatives (media, internet, etc.), teenagers often say they are bored with school". Deci et al. (1991, p. 325) argue that "the ideal school system is the one that is successful in promoting among students the enthusiasm for learning and self-realization, respectively a sense of volitional involvement in school structures". The classical education system based on the theoretical dimension is subject to criticism, and, more recently, "the emphasis is on learning through practical experience and work" (Giarini \& Maliţa, 2005, p. 55).

Although the share of the population aged between 30-34, with a level of tertiary education, has registered a constant increase, of approx. 5\% in recent years, the graduation rate of tertiary education is one of the lowest in the EU $(25.6 \%$ in 2015 , compared to $38.7 \%$ in the EU). This situation is caused by several factors that reduce young people's access to tertiary education such as the relatively low passing rate of the baccalaureate exam and the high rate of early school leaving. Additionally to these factors, there are other realities that can lead to the decision to drop out of tertiary studies such as insufficient relevance in the labour market of some of the university specializations or limited opportunities in university programs to develop transversal skills, considered 
valuable for increasing employability. The assumption in the National Strategy for Tertiary Education (2015) of objectives such as improving participation at all levels of tertiary education and the development of flexible, high quality, and labour marketrelevant curricula, are goals in which this strategy may be anchored. The number of university centres or university education programs we have in Romania is a generous one. A relevant example for this stat is represented by a report published by the European Commission in 2017 (EC, 2017) that ranks Romania as being 3rd in the European Union in terms of university dropout. The average reported at the level of the European Union is $11 \%$, while for Romania we have an average of $18 \%$.

\section{Theories on educational dropout in higher education}

The main paradigm in research on dropout and academic persistence is "The Model of Student Integration", proposed by Tinto (1975). In this model, dropout is seen as a result of the following factors: characteristics of the student, prior to their entry into studies (family background, high school education, individual skills and abilities), goals and initial commitments (goals for their own career, commitment compared to the institution where it was admitted) academic (institutional experiences in the academic environment that include school performance, intellectual development) and social (institutional experiences in the academic environment that includes interaction with teachers and colleagues), goals and final commitments (educational goals and career influenced by institutional experiences).

Another well-established model is "The Student Dropout Model", developed by Bean and Metzer (1985) which emphasizes the role that events external to the academic context play in fostering dropout (e.g., financial resources). However, subsequent studies have shown that the best understanding of academic dropout is provided by the integrative approach of the two models (Sandler, 2000). Although this integrative model does not explain much more of the variant of abandonment than previous models $43 \%$ compared to $45 \%$ ) its merit is that it analyses more accurately the complexity of the abandonment phenomenon than previous models (Sandler, 2000). It includes some important concepts for understanding dropouts such as self-efficacy in the decision on one's career, perceived stress, financial difficulty while emphasizing that financial aid has a beneficial effect on student retention.

Student involvement represents another factor proposed in the literature with effects on educational dropout, tested in numerous empirical studies (Berger \& Milem, 1999). Student involvement is defined as physical and psychological energy dedicated by the student to academic experience (Astin, 1984). Thus, it was found that the involvement of students in activities with teachers and colleagues has a positive effect on the retention of students in the university. The involvement behaviours shown by students since the beginning of the first semester are a good predictor of further studies in the next year. In general, the models presented above are briefly useful to explain the phenomenon of 
academic dropout found in various groups of students. For example, adult students can spend less time studying than traditional students or students from minority groups.

\section{Who are those who drop out of college?}

Recent studies (Edwards \& McMillan, 2015), conducted internationally, show that there are several characteristics regarding the types of students who drop out most frequently. Firstly, the completion rate is low for students enrolled in part-time education, those from isolated geographical areas, students over 25 years of age, and those with low socioeconomic status. Secondly, the dropout rate increases when a student belongs to several risk groups at the same time. For example, students with low socio-economic status are usually enrolled in part-time courses because they must work to support their studies financially. In their case, when the factors are cumulated, the risk of dropout increases (54\%) compared to that of students from poor socio-economic backgrounds (31\%) who are exposed to only one risk factor. Moreover, if their age exceeds 25 years, they are exposed to a much higher risk of abandonment (57.4\%). More than that, most students drop out in the first year of college, academic integration being an important factor in explaining further studies, and the presence, during this period, of the intention to continue is the best predictor of further studies. However, it should be noted that, at different levels of study, the factors influencing dropout are different (Edwards \& McMillan, 2015).

A series of recent studies highlight the external nature of causes for educational dropout, considering (Sahin, Arseven \& Kiliç, 2016) that are not associated directly with the educational system. The main external categories of factors found in the literature are familial factors and community level factors. Community level factors include segregated and isolated communities with high levels of unemployment and criminality. Familial factors encompass poverty situation, mono-parental families, traditional culture that force the youngsters to assume early roles for directly providing for the family and inconsequence to not attend or leave early their educational track (Sahin, Arseven, \& Kiliç, 2016). The turning point of the reorganizations of the educational system is defined especially by the new relations with the family. Thus, instead of the distance and the autonomous functioning of the family and the school, collaboration occurs to preserve the continuity between the family and the school relationship in the child's living environment.

For example, students who drop out in the first year of college attribute an important role to external factors, such as the job-study conflict. Students that drop out later, in final years, invoke poor academic integration as a reason for dropping out. Dropout may also be influenced by the following academic factors: insufficient correlation of curricula with employers' expectations and labour market requirements, insufficient number of accommodations in dormitories, insufficient number of scholarships available for lowincome students, limited access to counselling and mentoring activities, disproportionate expectations from courses about the contents taught. In general, however, students who 
drop out of school consider academic as well as financial factors as the main reasons for dropping out. Dropping out of higher education is influenced by lack of finances, which causes students to occupy early a place on the labour market, to the detriment of attending classes and seminars. Many of the students that are also employed, come from families with low financial potential, and are forced to work to support themselves. Once employees, they are forced to have their study time reduced, and no longer participate in courses and seminars, accumulate failed exams, and thus the phenomenon of social disinsertion occurs. In such situations, it is recommended to identify the students with educational potential and introduce them in financial support programs. An analysis made by the National Alliance of Student Organizations in Romania shows that the university dropout rate has as main cause financial elements, in the first instance, closely followed by the wrong choice of specialization or faculty. Specifically, 40\% of Romanian students drop out in the first year of study, and $41 \%$ of dropout students believe that this is caused by the wrong choice of specialization.

\section{Students dropout rates for the last three generations of bachelor level studies - Study case: The Faculty of Sociology and Psychology from West University of Timișoara}

In order to depict the evolution of students' dropout rates, a secondary data analysis was undertaken using official data collected from the yearly reports published by the Faculty of Sociology and Psychology from West University of Timișoara. The faculty is the second largest from WUT, being in the last years one of the faculties on the raise from the perspective of number of students. As structure, the faculty has four main departments: Social Work (with two bachelor programs and one masters program), Psychology (with one bachelor program and three masters programs), Sociology (with two bachelor programs and two masters programs) and Educational Sciences (with three bachelor programs and two masters programs).

\section{Research design}

The data collection focused on the last three generation of bachelor level students (20152018, 2016-2019 and 2017-2020) from each of the four departments of the faculty.

The data collected was structured on the following aspects: (1) the number of students that started in the first year; (2) the number of students that started the second year; (3) the number of student that started the third year; (4) the number of student that graduated bachelor studies after the third year; and (5) the number of students that passed the license exam.

To follow the dropout rate evolution, four dropout rates were calculated: the first dropout rate as percentage of students lost between the $1^{\text {st }}$ and $2^{\text {nd }}$ year of study; the second dropout rate as percentage of students lost between the $1^{\text {st }}$ and $3^{\text {rd }}$ year of study; the third dropout rate as the percentage of students lost from the start of the $1^{\text {st }}$ year and 
the finalisation of the $3^{\text {rd }}$ year (all exams passed); and the final dropout rate was calculated as the percentage of students lost from the start of the $1^{\text {st }}$ year and the finalisation of the licence exam.

\section{Data analysis:}

The data analysis section is structured on the four departments of the faculty and follows the specific tendencies on dropout for each of them.

\section{The Social Work Department}

As depicted in Table 1, the final dropout rate mean of the students from the Social Work Department is 42,66 percent (calculated as the mean of the two available Final dropout rates available).

Table nr. 1. Three generation dropout rates from bachelor level students of the Social Work Department

\begin{tabular}{|c|c|c|c|c|c|c|c|c|c|}
\hline $\begin{array}{l}\text { Social work } \\
\text { Department }\end{array}$ & $\begin{array}{l}\text { Start } \\
\text { ed } \\
1^{\text {st }} \\
\text { year }\end{array}$ & $\begin{array}{l}\text { Start } \\
\text { ed } 2^{\text {nd }} \\
\text { year }\end{array}$ & $\begin{array}{l}\text { Drop } \\
\text { out } \\
\text { rate } 1 \\
(\%) \\
\end{array}$ & $\begin{array}{l}\text { Start } \\
\text { ed } 3^{\text {rd }} \\
\text { Year }\end{array}$ & $\begin{array}{l}\text { Drop } \\
\text { out } \\
\text { rate } 2 \\
(\%) \\
\end{array}$ & $\begin{array}{l}\text { Finish } \\
\text { ed } 3^{\text {rd }} \\
\text { year }\end{array}$ & $\begin{array}{l}\text { Drop } \\
\text { out } \\
\text { rate } 3 \\
(\%) \\
\end{array}$ & Licensed & $\begin{array}{l}\text { Final } \\
\text { droout } \\
\text { rate } \\
(\%) \\
\end{array}$ \\
\hline \multicolumn{10}{|l|}{$2015-2018$} \\
\hline $\begin{array}{c}\text { Bachelor } \\
\text { level } \\
\text { generation } \\
\text { 2016-2019 }\end{array}$ & 72 & 55 & 23,61 & 58 & 19,44 & 37 & 48,61 & 37 & 48,61 \\
\hline $\begin{array}{c}\text { Bachelor } \\
\text { level } \\
\text { generation }\end{array}$ & 79 & 70 & 11,39 & 61 & 22,78 & 53 & 32,91 & 50 & 36,71 \\
\hline $\begin{array}{c}2017-2020 \\
\text { Bachelor } \\
\text { level } \\
\text { generation }\end{array}$ & 97 & 82 & 15,46 & 75 & 22,68 & NA & $N A$ & NA & $N A$ \\
\hline
\end{tabular}

The dropout rate from the $1^{\text {st }}$ year to the $2^{\text {nd }}$ year ranges between 11,39 percent and 23,61 percent, fluctuating in each generation. The dropout rate from the $1^{\text {st }}$ year to the $3^{\text {rd }}$ year is sensibly similar for all three generations ranging between 19,44 percent to 22,78 percent $^{1}$. The dropout rate from the end of the third year and the final dropout rates register similar values (the same for the 2015-2018 generation, and with a small difference for the 2016-2019 generation - from 32,91 percent to 36,71 percent), meaning that almost all the students that manage to graduate the three year bachelor study program are also managing to pass the licence exam.

\section{The Psychology Department}

The highest Final dropout rates are registered at the Psychology Department, with a calculated mean of 60,99 percent (Table 2).

Table nr. 2. Three generation dropout rates from bachelor level students of the Psychology Department

${ }^{1}$ The second dropout rate can have values lower than the first dropout rate due to the students that previously have temporarily dropped out from the studies and re-register for continuing them. 


\begin{tabular}{|c|c|c|c|c|c|c|c|c|c|}
\hline $\begin{array}{l}\text { Psychology } \\
\text { Department }\end{array}$ & $\begin{array}{l}\text { Start } \\
\text { ed } 1^{\text {st }} \\
\text { year }\end{array}$ & $\begin{array}{l}\text { Star } \\
\text { ted } 2^{\text {nd }} \\
\text { year }\end{array}$ & $\begin{array}{l}\text { Drop } \\
\text { out } \\
\text { rate } 1 \\
(\%)\end{array}$ & $\begin{array}{l}\text { Start } \\
\text { ed } 3^{\text {rd }} \\
\text { Year }\end{array}$ & $\begin{array}{l}\text { Drop } \\
\text { out } \\
\text { rate } 2 \\
(\%)\end{array}$ & $\begin{array}{l}\text { Finishe } \\
d 3^{\text {rd }} \\
\text { year }\end{array}$ & $\begin{array}{l}\text { Drop } \\
\text { out } \\
\text { rate } 3 \\
(\%)\end{array}$ & Licensed & $\begin{array}{l}\text { Final } \\
\text { drop } \\
\text { out } \\
\text { rate } \\
(\%)\end{array}$ \\
\hline $\begin{array}{l}\text { 2015-2018 } \\
\text { Bachelor } \\
\text { level } \\
\text { generation }\end{array}$ & 249 & 182 & 26,91 & 199 & 20,08 & 109 & 56,22 & 88 & 64,66 \\
\hline $\begin{array}{l}2016-2019 \\
\text { Bachelor } \\
\text { level } \\
\text { generation } \\
\text { 2017-2020 }\end{array}$ & 246 & 180 & 26,83 & 225 & 8,54 & 130 & 47,15 & 105 & 57,32 \\
\hline $\begin{array}{l}\text { Bachelor } \\
\text { level } \\
\text { generation }\end{array}$ & 241 & 172 & 28,63 & 207 & 14,11 & NA & $N A$ & NA & $N A$ \\
\hline
\end{tabular}

The dropout rate evolution for the students of the Psychology Department is particular, especially due to the high number of students that interrupted the studies at some point (temporarily dropped out) and decide to re-register for continuing, this influencing the intermediary dropout rates presented in table no. 2 .

The dropout rates from the $1^{\text {st }}$ year to the $2^{\text {nd }}$ year are similar for all the three generations of students, ranging from 26,83 percent to 28,63 percent. The second dropout rate analysed (from the $1^{\text {st }}$ year to the beginning of the $3^{\text {rd }}$ year) varies more, from 8,54 percent to 20,08 percent but without any chronological tendencies.

The dropout rates from the graduation moment are very high, these not being influenced by the re-registering process. They range from 47,15 percent to 56,22 percent. For the final dropout rates, considered after the licence exams, the percentage raises with approximatively 10 points for each of the two generations were data was available, reaching a range between 57,32 and 64,66 percent.

\section{The Sociology Department}

The Sociology Department registers the second highest Final dropout rate, with a mean of 45,86 percent (table 3 ).

Table $n$ r. 3. Three generation dropout rates from bachelor level students of the Sociology Department

\begin{tabular}{|c|c|c|c|c|c|c|c|c|c|}
\hline $\begin{array}{l}\text { Sociology } \\
\text { Department }\end{array}$ & $\begin{array}{l}\text { Start } \\
\text { ed } \\
1^{\text {st }} \\
\text { year }\end{array}$ & $\begin{array}{l}\text { Start } \\
\text { ed } 2^{\text {nd }} \\
\text { year }\end{array}$ & $\begin{array}{l}\text { Dropou } \\
\text { trate } 1 \\
(\%)\end{array}$ & $\begin{array}{l}\text { Start } \\
\text { ed } 3^{\text {rd }} \\
\text { Year }\end{array}$ & $\begin{array}{l}\text { Drop } \\
\text { out } \\
\text { rate } 2 \\
(\%)\end{array}$ & $\begin{array}{l}\text { Finished } \\
3^{\text {rd }} \text { year }\end{array}$ & $\begin{array}{l}\text { Drop } \\
\text { out } \\
\text { rate } 3 \\
(\%)\end{array}$ & Licensed & $\begin{array}{l}\text { Final } \\
\text { dropout } \\
\text { rate } \\
(\%)\end{array}$ \\
\hline $2015-2018$ & & & & & & & & & \\
\hline $\begin{array}{l}\text { Bachelor level } \\
\text { generation } \\
2016-2019\end{array}$ & 90 & 77 & 14,44 & 76 & 15,56 & 48 & 46,67 & 48 & 46,67 \\
\hline $\begin{array}{l}\text { Bachelor level } \\
\text { generation } \\
2017-2020\end{array}$ & 91 & 76 & 16,48 & 72 & 20,88 & 60 & 34,07 & 50 & 45,05 \\
\hline $\begin{array}{l}\text { Bachelor level } \\
\text { generation }\end{array}$ & 115 & 96 & 16,52 & 90 & 21,74 & NA & $N A$ & NA & $N A$ \\
\hline
\end{tabular}


The first dropout rate considered (that between the $1^{\text {st }}$ and the $2^{\text {nd }}$ year of study) is sensibly similar for all the three generations investigated, ranging from 14,44 to 16,52 percent, with a weak tendency of growth. The variation is higher for the dropout rates calculated at the beginning of the $3^{\text {rd }}$ year, ranging rom 15,56 to 21,74 percent, also with a growth trend for the later generations.

The dropout rates calculated at graduation have a different tendency, with large variance: the 2016-2019 generation registers a dropout rate with more that 10 percentual points lower than the 2015-2018 generation (34,07 compared with 46,67 percent). Despite this positive trend, the final dropout rate, considered after the licence exam, is almost the same for the two generations (45,05 and 46,67 percent).

\section{The Educational Sciences Department}

The lowest Final dropout rates are registered by the Educational Sciences Department, with a calculated mean of 31,33 percent (see Table 4).

Table nr. 4. Three generation dropout rates from bachelor level students of the Educational Sciences Department

\begin{tabular}{|c|c|c|c|c|c|c|c|c|c|}
\hline $\begin{array}{l}\text { Educational } \\
\text { Sciences } \\
\text { Department }\end{array}$ & $\begin{array}{l}\text { Start } \\
\text { ed } \\
1^{\text {st }} \\
\text { year }\end{array}$ & $\begin{array}{l}\text { Start } \\
\text { ed } 2^{\text {nd }} \\
\text { year }\end{array}$ & $\begin{array}{l}\text { Drop } \\
\text { out } \\
\text { rate } 1 \\
(\%)\end{array}$ & $\begin{array}{l}\text { Start } \\
\text { ed } 3^{\text {rd }} \\
\text { Year }\end{array}$ & $\begin{array}{l}\text { Drop } \\
\text { out } \\
\text { rate } 2 \\
(\%)\end{array}$ & $\begin{array}{l}\text { Finish } \\
\text { ed } 3^{\text {rd }} \\
\text { year }\end{array}$ & $\begin{array}{l}\text { Drop } \\
\text { out } \\
\text { rate } 3 \\
(\%)\end{array}$ & Licensed & $\begin{array}{l}\text { Final } \\
\text { drop } \\
\text { out } \\
\text { rate } \\
(\%)\end{array}$ \\
\hline $\begin{array}{l}\text { 2015-2018 } \\
\text { Bachelor } \\
\text { level } \\
\text { generation }\end{array}$ & 122 & 117 & 4,10 & 120 & 1,64 & 91 & 25,41 & 90 & 26,23 \\
\hline $\begin{array}{l}\text { 2016-2019 } \\
\text { Bachelor } \\
\text { level } \\
\text { generation }\end{array}$ & 129 & 117 & 9,30 & 118 & 8,53 & 99 & 23,26 & 82 & 36,43 \\
\hline $\begin{array}{l}\text { 2017-2020 } \\
\text { Bachelor } \\
\text { level } \\
\text { generation }\end{array}$ & 171 & 156 & 8,77 & 147 & 14,04 & NA & $N A$ & NA & $N A$ \\
\hline
\end{tabular}

Even if low the dropout rate between the $1^{\text {st }}$ year and the $2^{\text {nd }}$ year varies between generations from 4,10 to 9,30 percent with a tendency to grow for later generations. The variance is even higher for the dropout rate between the $1^{\text {st }}$ year and the beginning of the final year (between 1,64 and 14.04\%) also with a clear tendency to grow for the later generations. It is worth mentioning that also in the case of the Educational Sciences Department, the high number of re-registering after temporary dropout at the beginning of the $2^{\text {nd }}$ and the $3^{\text {rd }}$ year influences the data considerably.

Dropout rates at graduation are sensibly similar for the two generations with available data, ranging from 23,26 to 25,41 percent.

The final dropout rates, considered after the licence exam, differ for the two generations analysed. The 2015-2018 generation has almost the same rate as the graduation point (26,23 compared with 25,41 percent), but for the generation 2016-2019 
the dropout rate increased with more than 13 percent from the graduation until the licence exams (36,43 compared with 23,26 percent).

\section{Discussions and conclusions:}

As a general tendency of the dropout rate between generations of students, it can be observed that the last generations have lower rates in three out of the four departments analysed.

The dropout rates are high during the first and the third year $\left(1^{\text {st }}\right.$ and $3^{\text {rd }}$ dropout rate calculated). As a particularity for a department with large number of students, at the Psychology Department there is significant dropout also between the graduation and the licence exam.

In the present society, with its dynamic development, university level studies are extremely important. Highly specialised employees are needed on the labour market in order to face the quick pace of technological and social changes happening today. The right to quality education is fundamental for the individuals well-being and for the general development of the society.

The importance of addressing seriously, quickly, and effectively the educational dropout phenomenon at university level is obvious. The secondary analysis reveals high rates of the phenomenon and shows some trends, differentiated on departments and generations of bachelor level students. Mainly descriptive, the study will be continued and developed. Some of the research questions that result from the secondary analysis and need to be followed are: What are the main reasons for students to dropout from the educational system? What is the context in which later generations have the tendency to have higher dropout rates that the previous ones? Why high temporary dropout happens at the Psychology and Educational Department? What are the causes for the big gaps between the graduation dropout rates and the ones after the licence exams?

\section{References}

Astin, A. (1984). Student involvement: A developmental theory for higher education. Journal of College Student Personnel, 25(4), 297-308.

Bean, J., Metzer, B. (1985). A conceptual model of nontraditional undergraduate students' attrition. Review of Educational Research, 55(4), 485-540.

Berger, J. B., \& Milem, J. F. (1999). The role of student involvement and perceptions of integration in a causal model of student persistence. Research in higher Education, 40(6), 641-664.

Cummings, W., K. (2007). Instituţii de învăţământ. Bucureşti: Editura Comunicare.ro.

Deci, E., L., Vallerand, R., J., Pelletier, L.,G., \& Ryan, R.,M. (1991). Motivation and Education: The SelfDetermination Perspective. In Educational Psychologist, 26 (3 \& 4), pp. 325-346.

Edwards, D., McMillan. J. (2015). Completing university in a growing sector: insequrity an issue? ACER. 29

European Comission (2017) Raportul de țară al României din 2017, https://ec.europa.eu/info/sites/info/files/2017-european-semester-countryreport-romaniaro.pdf.

Giarini, O., Malița, M. (2005). Dubla spirală a învăţării şi a muncii. București: Editura Comunicare.ro. 
Johnstone, D. B., \& Marcucci, P. N. (2010). Financing higher education worldwide: Who pays? Who should pay? JHU Press.

Sahin, S., Arseven, Z., \& Kiliç, A. (2016). Causes of Student Absenteeism and School Dropouts. International Journal of Instruction, 9(1), 195-210.

Sandler, M. (2000). Career decision-making self-efficacy, perceived stress, and an integrated model of student persistence: A structural model of finances, attitudes, behavior, and career development. Research in Higher Education, 41(5), 537-580.

Tinto, V. (1975). Dropout from higher education: A theoretical synthesis of recent research. Review of Educational Research, 45(1), 89-125. 